\title{
The invariant method is manipulable
}

Citation for published version (APA):

Kóczy, L. Á., \& Strobel, M. (2008). The invariant method is manipulable. METEOR, Maastricht University School of Business and Economics. METEOR Research Memorandum No. 029

https://doi.org/10.26481/umamet.2008029

Document status and date:

Published: 01/01/2008

DOI:

10.26481/umamet.2008029

Document Version:

Publisher's PDF, also known as Version of record

\section{Please check the document version of this publication:}

- A submitted manuscript is the version of the article upon submission and before peer-review. There can be important differences between the submitted version and the official published version of record.

People interested in the research are advised to contact the author for the final version of the publication, or visit the DOI to the publisher's website.

- The final author version and the galley proof are versions of the publication after peer review.

- The final published version features the final layout of the paper including the volume, issue and page numbers.

Link to publication

\footnotetext{
General rights rights.

- You may freely distribute the URL identifying the publication in the public portal. please follow below link for the End User Agreement:

www.umlib.nl/taverne-license

Take down policy

If you believe that this document breaches copyright please contact us at:

repository@maastrichtuniversity.nl

providing details and we will investigate your claim.
}

Copyright and moral rights for the publications made accessible in the public portal are retained by the authors and/or other copyright owners and it is a condition of accessing publications that users recognise and abide by the legal requirements associated with these

- Users may download and print one copy of any publication from the public portal for the purpose of private study or research.

- You may not further distribute the material or use it for any profit-making activity or commercial gain

If the publication is distributed under the terms of Article $25 \mathrm{fa}$ of the Dutch Copyright Act, indicated by the "Taverne" license above, 
László Á. Kóczy, Martin Strobel

The Invariant Method is Manipulable

RM/08/029

\section{METEबrR

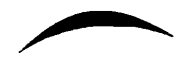

Maastricht research school of Economics of TEchnology and ORganizations

Universiteit Maastricht

Faculty of Economics and Business Administration P.O. Box 616

NL - 6200 MD Maastricht

phone : ++31433883830

fax : $\quad++31433884873$ 


\title{
The Invariant Method is Manipulable*
}

\author{
László Á. Kóczy ${ }^{\dagger}$ and Martin Strobel ${ }^{\ddagger}$
}

\begin{abstract}
We show that the invariant method (Pinski and Narin, 1976), recently axiomatised by Palacios-Huerta and Volij (2004), and used to quality-rank academic journals is subject to manipulation: a journal can boost its performance by making additional citations to other journals.
\end{abstract}

Keywords: quality ranking academic journals, invariant method, manipulation

\section{Introduction}

In a recent surge of interest in ranking academic journals Palacios-Huerta and Volij (2004) present an axiomatisation of the invariant method (Pinski

${ }^{*}$ The authors thank the funding by METEOR; Kóczy acknowledges the support of the European Union by a Marie Curie Intra-European Fellowship (MEIF-CT-2004-011537).

${ }^{\dagger}$ Corresponding author. Department of Economics, Maastricht University and Keleti Faculty of Economics, Budapest Tech Tavaszmező 15-17, H-1084 Budapest. Email: koczy.laszlo@kgk. bmf .hu

${ }_{\ddagger}^{\ddagger}$ Department of Economics, Maastricht University. 
and Narin, 1976) as the unique distribution vector that satisfies anonymity, invariance to citation intensity, weak homogeneity, weak consistency and invariance to splitting of journals. While many other ranking methods have been proposed in the past, mostly without motivation. Palacios-Huerta and Volij (2004) give an axiomatisation for the invariant method by a number of attractive properties.

With journal rankings playing a more and more prominent role in academics, both in personnel and funding decisions, the incentives to improve one's journal's rank, possibly by manipulation, is there. Indeed, for most ranking methods the rank of a journal can be improved by changing its characteristics or its citation pattern. We show that the invariant method is no exception here.

In the following we elaborate on the idea of manipulation and prove our claim by an example.

\section{Manipulation}

The invariant method and its properties highlight a number of problems in comparing journals of different fields. While a bias in this sense is unfortunate, such differences can be accounted for. For instance, increasing a journal's citation intensity would only be beneficial if also citing journals would increase theirs, such a concerted effort is, however, unlikely and comes with incentives to free ride. 
On the other hand, possibilities to manipulate rankings, that is, to boost a journal's ranking unilaterally we must view with concern. In their presence a ranking reflects quality, but also the strategic attitude of the publisher or the editor.

Manipulation can take various forms. Since the impact factor (Garfield, 1955) - calculated as the cites per article ratio in a window of two years has become the standard to evaluate journal quality, publishers and editors have inquired about the exact method of its computation (Jennings, 1999) only to realise that it can be manipulated by classifying papers as "letters to the editor" and not as "articles" (Didierjean, 2002). While this affects the impact factor and rankings based on it, a more sophisticated ranking method can account for such deviations and present a more correct ranking.

It is therefore more fortunate if the manipulation involves the citations themselves. A citation refers to information that is not originally created in the citing journal, but has appeared earlier in the cited journal. Receiving a citation indicates that a result was found useful elsewhere. It is therefore not surprising that citation analysis is used to evaluate the quality of journals; if rankings can be manipulated by changing citation patterns the very meaning of citations is questioned affecting science itself.

Citations can be manipulated by adding or removing citations. It is important to stress that any ranking using citation analysis is subject to manipulation if we allow for the latter - ad absurdum a journal not making any citations could be ranked top by, for instance, the LP method (Liebowitz 
and Palmer, 1984). We can only assume that such a practice would swiftly be rejected by the scientific community.

Adding self-citations has often the same effect: while the use of external results is acknowledged, their importance is diminished by the more extended use of results from the home journal. Self citations can manipulate the impact factor (Smith, 1997), the LP- and the invariant method.

While, in a somewhat controversial step, these gratuitous citations can be neutralised by ignoring self-citations altogether, manipulation by making additional citations to other journals is shakes the foundations of citation analysis.

That this kind of manipulation is possible is strange and almost paradoxical. An additional cite suggests that the results published are less original, but taken from elsewhere. Such a cite should (weakly) improve the cited journal's rank, while the journal in question should (weakly) drop in the ranking. Should such manipulation be possible, the ranking method would fail some natural monotonicity criterion. Non-manipulable ranking methods exist (Kóczy and Strobel, 2007).

\section{An example}

Proposition. The ranking based on the invariant method is manipulable by making additional citations to other journals.

Proof. Consider the example with journals $\{1,2,3,4\}$ each publishing 2 arti- 
cles (Using the notation of Palacios-Huerta and Volij (2004) $a_{1}=a_{2}=a_{3}=$ $a_{4}=2$.) and a citation matrix given by

$$
C=\left(\begin{array}{llll}
0 & 1 & 1 & 1 \\
1 & 0 & 0 & 2 \\
1 & 1 & 0 & 0 \\
1 & 0 & 1 & 0
\end{array}\right) .
$$

The invariant method gives the vector $v=(30,24,22,21) / 97$ ranking journal 4 the lowest. Now suppose this journal makes 2 additional citations to journal 1 . The citation matrix is modified as follows:

$$
C^{\prime}=\left(\begin{array}{llll}
0 & 1 & 1 & 3 \\
1 & 0 & 0 & 2 \\
1 & 1 & 0 & 0 \\
1 & 0 & 1 & 0
\end{array}\right),
$$

and the corresponding invariant vector is given by $v^{\prime}=(54,32,34,35) / 155$. In the ranking based on the new invariant vector journal 4 is ranked second, overtaking journals 2 and 3.

The example is not very special, the problem is generic: Adding citations to highly ranked journals diminishes the value of other citations giving other cited journals a lower score.

That the invariant method can be manipulated by self-cites is fairly trivial. 


\section{Conclusion}

We have shown that the invariant method is subject to manipulation: a journal's rank can be improved by making additional citations, possibly to other journals.

We consider non-manipulability an important property, even more important than some of the properties used by (Palacios-Huerta and Volij, 2004), for instance invariance to citation-intensity. While journals in higher citation-intensity fields are often ranked better, citation intensity is an exogenous variable that can hardly be changed. A unilateral increase of citationintensity is unlikely to be beneficial, while coordinated efforts in a field are subject to free riding. Manipulation, in contrast, allows for publishers and editors to boost their indicators by unilateral steps. A manipulation-free ranking should let them focus on genuine quality.

\section{References}

DidierJean, X. (2002): “"Editors! Check Your Impact Factor Data!” Letters to Dermatology Count More towards the Calculation of the Impact Factor than in Any Other Dermatology Journal," Dermatology, 205(4), $327-328$.

Garfield, E. (1955): "Citation indexes to science: a new dimension in documentation through association of ideas," Science, 122(3159), 108-111. 
Jennings, C. (1999): "Citation data: the wrong impact?," Neuroendocrinology Letters, 20(1-2), 7-10.

Kóczy, L. Á., And M. Strobel (2007): "Ranking Academic Journals by Tournament Methods," Mimeo.

Liebowitz, S. J., And J. C. PAlmer (1984): "Assessing the Relative Impacts of Economics Journals," Journal of Economic Literature, 22(1), $77-88$.

Palacios-Huerta, I., And O. VoliJ (2004): "The Measurement of Intellectual Influence," Econometrica, 72(3), 963-977.

Pinski, G., ANd F. NARIN (1976): "Citation Influence for Journal Aggregates of Scientific Publications: Theory, with Application to the Literature of Physics," Information Processing \& Management, 12(5), 297-312.

Smith, R. (1997): "Journal accused of manipulating impact factor," British Medical Journal, 314(7079), 461. 